\title{
Shifting the policy paradigm of solar photovoltaic and other renewable energy technologies supply in rural Ghana
}

\author{
Simon Bawakyillenuo ${ }^{1, *}$ \\ ${ }^{1}$ Institute of Statistical, Social and Economic Research, University of Ghana, Accra, Ghana \\ *Corresponding author.Tel: +233275224939,E-mail: bawasius@hotmail.com
}

\begin{abstract}
Energy, inter alia, other structures, have been sine qua non to socio-economic development, enhancement of rural production and food security, improvements in healthcare and standards of living in human societies. Currently, while energy can help extricate rural societies in the developing world from poverty and augment development, they can only be realised through the implementation of effective energy policy approaches. Employing instruments from both qualitative and quantitative methods to analyse data gathered from two solar PV projects' sites in Ghana as case studies, the paper explores the interface between the policy approaches that have been used for the supply of electricity to rural Ghana, and the energy needs of these rural communities. The paper concludes that, due to the prevalence of poverty among rural societies in Ghana and other parts of the developing world, energisation and not electrification, is the optimal policy paradigm that will underpin rural socio-economic development and the adoption of renewable energy technologies (RETs).
\end{abstract}

Keywords: Rural Electrification, Renewable Policy, Energisation

\section{Introduction}

The positive interconnectivity between energy and the plenary human development dates back to the beginning of human existence. Energy, inter alia, other structures, have been sine qua non to socio-economic development, enhancement of rural production and food security, improvements in healthcare and standards of living in human societies. Unequivocally, therefore, energy has a pivotal role to play in the attainment of the goals of the twined global development paradigms: sustainable development and the 'Millennium Development Goals' (MDGs), despite the non-explicit mention of energy in any of the MDGs. The argument is that, communities, both rural and urban, will be well placed to achieve both social and economic prosperity and poverty alleviation once they have access to effective, reliable and affordable modern energy services (The EU Energy Initiative, 2006; Bawakyillenuo, 2009). Conversely, the upshot in the absence of adequate, affordable, reliable and safe modern energy services is stunted socio-economic development - a manifestation of poverty (Department for International Development, 2002). The International Energy Agency (IEA) (2002), corroborated the importance of energy in the socio-economic fabric of rural areas, by outlining the adverse effects of its non-existence: "[the] lack of electricity exacerbates poverty and contributes to its perpetuation, as it precludes most industrial activities and the jobs they create" (p.33). It has been estimated that an additional 700 million people worldwide will need to be provided with reliable and affordable modern energy services by 2015, in order to meet the MDG poverty reduction target (Flavin and Aeck, 2004).

Notwithstanding the importance of energy in fostering development, globally, about 1.6 billion people are without access to modern forms of energy especially, electricity, while 2.4 billion people rely on traditional biomass fuels for their energy needs (DFID, 2002; Flavin and Aeck, 2004; Niez, 2010). Predominantly, these people are found within the rural areas of developing countries especially, Sub-Saharan Africa and South Asia (Duke et al, 2002; Niez, 2010). For instance, more than $83 \%$ of Africa's rural population is without electricity, with an incremental figure of 92\% in Sub-Saharan Africa (Bawakyillenuo, 2009). In a similar vein, 
traditional biomass fuels account for about $70-90 \%$ of primary energy supply and up to 95\% of the total consumption in some African countries (Karekezi, 2002).

The original approach, and still, the dominant in the supply of electricity to rural areas in the developing world, is centralisation, which involves the distribution of power from the grid (Bawakyillenuo, 2009). Almost all Sub-Saharan African countries follow this centralised grid-based strategy in rural electricity supply. An alternative approach, which has been favoured by many individuals, nations and organisations, is the decentralised approach: the usage of decentralised sources of energy generation technologies particularly, 'new' renewables (micro hydropower, solar PV, wind, biofuel, solar thermal electric and geothermal), diesel-engine generator set or hybridisation of any of these energy technologies. The hyper support for the latter approach notably, the utilisation of 'new' renewables, emanates from their environmental benignity, modularity, least-cost advantage on a life-cycle basis compared with grid and diesel generators. Using life-cycle accounting and externalities associated with energy systems as the yardsticks, renewable energy technologies are costcompetitive as well as reliability-competitive with conventional energy sources in many applications including, off-grid electrification with solar photovoltaic (PV), solar photovoltaic pumping (PVP) irrigation systems etc., (IEA-PVPS T9-07, 2003; Flavin and Aeck, 2004). 'New' renewables also have the potentials to offset the vulnerability of developing countries to oil price spikes, reduction in both import dependence burden on foreign exchange (Radulovic, 2005; Flavin and Aeck, 2004). However, it is still quite elusive with respect to whether the use of both approaches (centralised and decentralised) in the supply of electricity to rural populations, always have the desired effects on them.

Predicating the argument on analysed data from two solar PV projects' sites in Ghana as case studies, this paper explores the interrelationship between the policy approaches that have been used to supply electricity to rural Ghana, and the energy needs of these rural communities. In particular, it examines the extent to which these policy approaches have helped serve the energy needs of these communities after solar PV and other RETs were incorporated in the Rural Electrification Programme (REP). It concludes with recommendations for the energy policy approaches that could be the panacea to poor rural communities' needs in Ghana and other developing countries.

\section{Rural electrification versus energisation - a contextual account}

Energy encompasses light, heat, mechanical power and electricity from various sources of fuels - fossil fuels and renewable energy sources (DFID, 2002). The need or desire for energy, therefore, is a 'derived demand' from the demand for varied energy services - cooking, water heating, lighting, refrigeration, water pumping for productivity, transport, communications, etc. Rural electrification and energisation are two different sources providing these energy services.

Rural electrification has been defined diversely. However, the points of divergence are centred on the approaches (centralised, decentralised or both) used in the supply of the electricity. For instance, some observe rural electrification to be the extension of the central grid to rural areas. Conversely, rural electrification has been viewed as the process by which access to electricity is provided to households or villages in isolated or remote parts of a country irrespective of the approach (Niez, 2010). Characteristic of rural electrification in the developing world is the emphasis on lighting service to the exclusion of cardinal services especially, productivity (DFID, 2002). Although lighting enhances off-farm productive 
activities, on the whole, rural electrification programmes are usually devoid of responding holistically to the energy needs of the rural poor. Many rural electrification programmes are top-down in approach. Often, huge sums of money are spent to extend grid to selected rural areas without any consideration to the availability of adequate generation capacity (Ramakumar, 2007).

The concept of energisation on the hand is very holistic. It embraces electrification, and emphasises on the provision of the composite varied energy services, based on the needs of the rural beneficiary communities. Unlike rural electrification, the central theme of energisation focuses on matching the needs of end-users of energy services with available resources (Ramakumar, 2007). Therefore, notwithstanding the approaches (centralised, decentralised, or both) used to supply energy services to beneficiary communities, the existence of such services are usually fulfilling the expressed energy needs of the communities, hence, will have more support from them. In other words, the delivery of energy services through energisation programme follows the bottom-up approach.

\section{Geography, energy perspectives and socio-economic issues of Ghana}

Surrounded by Cote D'Ivoire, Burkina Faso, Togo and the Atlantic Ocean, Ghana is between $4^{0}$ and $12^{0}$ degrees north latitude, and longitude $30^{\circ} \mathrm{W}$ and $1^{0} \mathrm{E}$. The climatic conditions range from warm and relatively dry along the southeast coast, hot and humid in the southwest, and hot and dry in the north. With an approximate population of 22.4 million, coupled with an estimated annual growth rate of 2.7\%, 54 and 46 percent are rural and urban respectively (Bawakyillenuo, 2009).

Ghana, abounds with renewable energy resources (hydro, solar, wind, biomass, etc), and has a considerable amount of oil deposit in the off-shore. The country's energy consumption is estimated at 6.6 million tonnes of oil equivalents (TOE) with an estimated per capita consumption at 360 kilograms of oil equivalent (KOE). Traditional fuels constitute $59 \%$ of the total consumption, whilst petroleum products and electricity account for 32\% and 9\% respectively. Though with majority of the population in the rural areas, an inverse relationship exists concerning access to modern sources of energy between the urban and rural areas. About $17 \%$ of the total rural population, and only $5 \%$ in the rural population of the northern part of the country, have access to electricity, juxtaposing with $77 \%$ access in the urban area (Bawakyillenuo, 2009). The lighting and cooking energy services' needs of the rest of 83\% are derived from traditional fuels - kerosene, candles, dry cell batteries, oil lamp, etc (ibid). Modern energy services for productive activities especially, cottage industries, irrigation farming, etc., are either non-existent or negligible in these rural areas (Bawakyillenuo, 2007).

In response to the Economic Recovery Programme (ERP) of the 1980s, the Government of Ghana instituted the National Electrification Scheme (NES) in 1989 principally, as the tool for the extension of the grid to the nooks and cranny of the country, especially all district capitals, towns and villages exceeding 500 inhabitants, over a thirty-year period (1990-2020) (Abavana, 2004). The Self-Help Electrification Project (SHEP) was later initiated to complement NES: it makes provisions for communities within $20 \mathrm{~km}$ radius of existing $33 \mathrm{KV}$ or $11 \mathrm{KV}$ sub-transmission line to speed up their electrification projects, once they secure all poles for the low voltage network with $30 \%$ of houses wired. In 2001, the Government of Ghana mainstreamed solar PV and other renewable energy technologies in the REP. 
With respect to the economy, Ghana has approximately twice the per capita output of poorer West African countries, with an estimated per capita GDP at \$2,600 in 2006 (CIA World Factbook - Ghana, 2007). Agriculture (farming, rearing and fishing) is the mainstay of the economy, accounting for 37.3\% of GDP (2006) and 60\% workforce; followed by the service sector with $25 \%$ workforce; and industry - $15 \%$ percent (ibid). The rural economies within the three belts of the country (coastal, middle and northern) are fundamentally based on rainfed agriculture, $90 \%$ of which is peasant-based. In the coastal belt, fishing is the main occupation followed by livestock rearing; in the middle belt with bimodal rainfall regime, crop farming predominates, followed by livestock rearing and fishing; and in the northern belt with a unimodal rainfall regime, crop farming and livestock rearing are the main economic activities. The northern belt (the two solar projects' zone) is frequently subjected to poor yields and food shortages, because of the single rainfall regime, climate variability and lack of facilities to undertake complementary farming activities in the dry season. Though richer than other poorer West African nations, poverty is still pervasive in the rural areas of Ghana, since rain-fed agriculture is the main occupation. Incidence of poverty is quite acute in the rural areas, accounting for $84 \%$ of Ghana's poor - the northern belt ranks the highest in poverty.

\section{Wechiau and Bunkpurugu/Yunyoo's PV solar household system (SHS) projects}

The two case studies were carried out through field survey in 2005 by the author as part of his PhD thesis' fieldwork. The projects are the Government of Ghana/Spanish Government offgrid solar PV rural electrification project in Wechiau in Wa West District (1998) and the UNDP/GEF/Ghana Government Renewable Energy Service Project (RESPRO) in Bunkpurugu/Yunyoo District in 1999. The goal of the Wechiau project was to assess the social, economic and technical performance of solar PV as an instrument for rural electrification in off-grid communities. The project comprised of a battery centre and PV/SHSs, with the implementing body being the Ministry of Energy (MOE). The financing mechanism used to supply the PV/SHSs to customers was the fee-for service. While customers paid a flat installation fee of $\$ 100,000$ cedis (US\$13.92), users of both the $50 \mathrm{Wp}$ and 100Wp modules paid $\$ 15,000$ (US\$2.09) and $\$ 25,000$ (US\$3.48) monthly tariffs respectively. The Wechiau project was managed by two formal indigenous groups after its implementation (i.e. operators of the battery charging centre and a solar committee) with different responsibilities. Operators of the battery charging centre were tasked with charging of batteries commercially, passing the fees charged onto the solar committee, and undertaking basic servicing of the installed PV/SHS. The solar committee on the other hand, was to collect the monthly tariff from the users on behalf of the MOE and deposit it at the bank.

Implemented from 1999 to 2004, the main aim of RESPRO was to initiate the development of a commercial market for renewable-based electricity services in rural Ghana, with an initial emphasis on PV/SHS. An individual customer could apply for one of two PV/SHSs, 50Wp and $100 \mathrm{Wp}$. Because the main market model was the fee-for-service, customers paid a $\$ 250,000$ (US\$34.86) installation fee and $\$ 90,000$ (US\$12.55) six months advanced tariff for $50 \mathrm{Wp}$ SHSs before installation was carried out. On the other hand, customers wanting $100 \mathrm{Wp}$ SHSs paid a $\$ 500,000$ (US\$69.72) installation fee and 150,000 (US\$20.91) six months advanced tariff. Six months after installation, customers began paying monthly tariffs $\$ 15,000$ (US\$2.09) for a 50Wp system and $\$ 25,000$ (US\$3.48) for a $100 \mathrm{Wp}$ system. A default in paying the tariff for three months resulted in the removal of the system. RESPRO was implemented by a subsidiary unit of the MOE, which was formed through the secondment of some of its personnel. Personnel included a national co-ordinator in Accra, two engineers and 
six field technicians, who were responsible for the installation and maintenance of the solar PV systems.

\section{Methodology}

Data for this paper were gathered using, documentary gathering of energy policy literature of Ghana; formal and informal interviews with three PV technicians who worked on the two PV/SHS projects, three officials at the Ghana's energy ministry; the administering of households questionnaires to twenty PV/SHS users, twenty non-PV/SHS users and four cottage industrialists. Of particular importance were the incorporation of the Likert scale of measurement and a weighting system based on ranked choices, in the questionnaires. In the application of the Likert scale, respondents indicated the strength of agreement or disagreement on series of statements. In the case of the weighting system, a defined ranking scale (1, being the least, and 10, the maximum) was used, and respondents were asked to indicate their preferences/choices on a set of energy related issues having recourse to this scale. As a result, the total responses for a particular choice are multiplied by its position in a descending order, and the weights are then summed up to reveal the relativity in choices. The various themes addressed in the questionnaires were: the socio-economic features of PV/SHS adopters and non-adopters, sources of the various energy services in the rural areas, factors underpinning the adoption and non-adoption of PV/SHS, knowledge on energy policy, etc. Content analysis, Statistical Package for Social Scientists (SPSS) and Excel were the analytical tools. A limitation of this paper is the small sample size. However, this is catered for, as emphasis is on policy analysis and not statistical significance or econometric analysis.

\section{Results}

Results of the processed data are presented in the below figure and tables. Also, manifest in the results are the following associated features of the two PV/SHS projects: most of the rural dwellers did not adopt the PV/SHSs; withdrawal of qualified technicians after the projects' implementation phases; malfunction of majority of the installed PV/SHSs; lack of maintenance services after the projects' implementation phases.

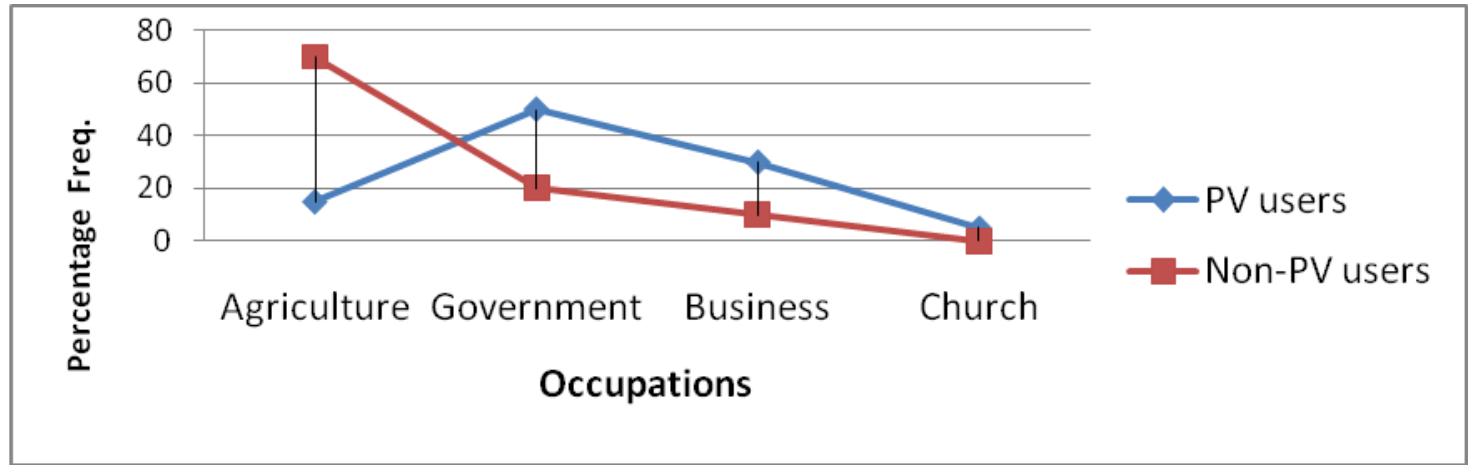

Fig. 1. Occupations of respondents (40) with and without PV/SHS at the two case study areas

Table 1. Main uses of PV/SHS by beneficiaries (20) in the two case study areas

\begin{tabular}{ccc}
\hline Uses & Frequency & Percent \\
\hline Lighting & 20 & 100 \\
Entertainment & 15 & 75 \\
Business & 4 & 20 \\
Cooking & 0 & 0 \\
Education & 7 & 35 \\
Agriculture & 0 & 0 \\
\hline
\end{tabular}


Table 2. Reasons for the non-adoption of PV/SHS by non-users (20) in the two case study areas

\begin{tabular}{ccc}
\hline Reasons & Number & Percent \\
\hline Expensive & 20 & 100 \\
Prefers grid & 12 & 60 \\
Inaccessible & 10 & 50 \\
Lack of PV know-how & 9 & 45 \\
Unreliable & 8 & 40 \\
\hline
\end{tabular}

Table 3. Relative importance of various energy services to PV/SHS users and non-users

\begin{tabular}{lcccccccccc}
\hline & \multicolumn{2}{c}{ Lighting } & \multicolumn{2}{c}{$\begin{array}{c}\text { Agriculture } \\
\text { (irrigation) }\end{array}$} & \multicolumn{2}{c}{ Cooking } & Entertainment & \multicolumn{2}{c}{$\begin{array}{c}\text { Cottage } \\
\text { industry }\end{array}$} \\
\hline $\begin{array}{l}\text { Ranking } \\
\begin{array}{l}(1 \ldots 5) \\
\text { Very }\end{array}\end{array}$ & $\begin{array}{c}\text { PV } \\
\text { users }\end{array}$ & $\begin{array}{c}\text { Non } \\
\text { users }\end{array}$ & $\begin{array}{c}\text { PV } \\
\text { users }\end{array}$ & $\begin{array}{c}\text { Non } \\
\text { users }\end{array}$ & $\begin{array}{c}\text { PV } \\
\text { users }\end{array}$ & $\begin{array}{c}\text { Non } \\
\text { users }\end{array}$ & $\begin{array}{c}\text { PV } \\
\text { users }\end{array}$ & $\begin{array}{c}\text { Non } \\
\text { users }\end{array}$ & $\begin{array}{c}\text { PV } \\
\text { users }\end{array}$ & $\begin{array}{c}\text { Non } \\
\text { users }\end{array}$ \\
$\begin{array}{l}\text { important } \\
\text { Important }\end{array}$ & 6 & 4 & 2 & 6 & 5 & 7 & 5 & 2 & 3 & 4 \\
$\begin{array}{l}\text { Somewhat } \\
\text { important }\end{array}$ & 3 & 5 & 3 & 3 & 4 & 5 & 5 & 0 & 4 & 4 \\
$\begin{array}{l}\text { Less } \\
\text { important }\end{array}$ & 2 & 5 & 4 & 1 & 3 & 1 & 3 & 6 & 6 & 4 \\
$\begin{array}{l}\text { Least } \\
\text { important }\end{array}$ & 0 & 4 & 9 & 0 & 3 & 2 & 0 & 10 & 5 & 2 \\
$\begin{array}{l}\text { Weighted } \\
\text { score }\end{array}$ & 82 & 55 & 44 & 84 & 66 & 72 & 76 & 40 & 51 & 68 \\
\hline
\end{tabular}

Succinct explanation to the survey results in the figure and tables above is advanced. Figure 1, reveals the lopsidedness of the occupational characteristics between PV/SHS adopters and non-adopters: agriculture forming the main occupation of majority of non-adopters of PV/SHS and vice versa; and government work (civil service), the main occupation of majority of PV/SHS adopters and vice versa. The most important services from PV/SHS according to beneficiaries are lighting and entertainment (Table 1), while uses for agriculture are nonexistent. Non-adopters of PV/SHS see cost, preference for grid and inaccessibility to PV/SHS as the main reasons for their non-adoption of PV/SHS (Table 2). Table 3, also depicts a very disparate rankings between users and non-users of PV/SHS. Lighting, followed by entertainment, dominate the weighted scores by PV/SHS users, with agriculture the least. Inversely, agriculture, followed by cooking and cottage industry are the highest weighted scores by non-adopters of PV/SHS, with entertainment the least.

\section{Discussion and conclusion}

Critical analysis of the survey results, the socio-economic attributes of the rural people in Ghana and the energy perspectives of the country in tandem, raise key interrelated issues: accessibility to, and affordability of modern energy services by rural people; and the congruity/incongruity of Ghana's energy policy direction with the needs of the rural people.

\subsection{Accessibility and affordability}

Conjointly, accessibility and affordability are some of the key issues that emerged from the analysis of data for this paper. As indicated in the results section, a key feature of the case studies is that, most inhabitants in the PV/SHS projects' communities did not adopt the 
technology - a phenomenon that intertwines with accessibility and affordability etc. Accessibility dimension is particularly depicted in Table 2, whereby 10 out of the 20 nonusers of PV indicated inaccessibility as one of the reasons for their non-adoption of the technology. Six people out of the 10 that indicated inaccessibility were civil servants and business people, who could not adopt the solar PV/SHS before the projects ended. Notwithstanding the social group that pointed out inaccessibility as the hindrance, poor access to modern energy services is profound in rural Ghana as well as most rural societies in the developing world (Bawakyillenuo, 2009). With respect to the affordability trajectory, Table 2 reveals that cost (expensiveness) is a key factor to the non-use of PV/SHS, while Figure 1 depicts the occupation of majority of these non-users to be agriculture. The lack of affordability of PV/SHS by these non-users is highly correlated with the features of their occupation - rain-fed agriculture, which creates abject poverty among them (see section 3). Enhancing their affordability level can only be made possible by an increase in their incomes, hence, the need for concrete policies on productivity as well as financing. For example, it has been noted that 50 percent of rural households in the developing world will still be unable to afford solar PV even with the use of credit and fee-for-service financing models (Bawakyillenuo, 2007, citing Jacobson, 2004).

\subsection{Ghana's energy policy direction vis-à-vis the needs of rural communities}

Analysis of the energy policy documents and survey results reveal the unidirectional nature of the energy policy of Ghana in general, as well as on 'new' renewables. Emphasis on these technologies, especially PV (the only renewable technology in application in Ghana), is electrification. The onset of PV utilisation was premised on the fact it was virtually impossible to electrify certain islands on the Volta Lake and remote areas via the grid (Abavana, 2004). The uni-focus nature of policy towards these 'new' renewables is buttressed by the main uses of PV/SHS by beneficiaries in the two study areas (Table 1). While lighting and entertainment services predominate the uses, direct application of motive power from PV for agricultural purposes are non-existent. This policy slant on 'new' renewables on the one hand, and the survey results in Table 3 on the other hand, bring out the incongruity between the policy and the energy needs of rural dwellers. The non-users of PV/SHS, who are predominantly peasant farmers, and riddled with poverty, place more value on energy services that will boost agriculture, cooking and cottage industry. Arguably, such energy services have the overall impact of increasing income levels. The choices by PV/SHS users (who are the middle class and the minority in the rural areas), however, contrast with those of the nonusers. The choices of PV/SHS users are not far-fetched because, their occupations can afford them certain amount of disposable incomes, which are enough to propel them up the rungs of the energy ladder (i.e. the desertion of the application of kerosene and dry cells to the utilisation of electricity from modern energy technologies). It is an established fact that, higher incomes enhance the ability to afford more energy (DFID, 2002).

The flagship outcome of this paper is that, the focus of energy policy in Ghana, even with the incorporation of RETs is that of electrification (lighting) - a faltered policy strategy, because it does not address the composite and core energy services needs of poor rural communities. Electricity is not always the most appropriate form of energy services to the poor (DFID, 2002). Irrespective of numerous solutions advanced by scholars and organisations for the expansive dissemination of RETs especially, PV in rural areas of developing countries, findings of this paper affirm that their slow adoption process and sustainability boil down to the disregard for appropriate policies measures. Effective policy structures act as stimulants to PV/SHS dissemination (Bawakyillenuo, 2009). 
As a result of the prevalence of poverty among rural societies in Ghana, and for that matter the developing world, energisation is the optimal policy trajectory for these areas. Through this policy approach, energy services needs of various social and income groups are met via the conduction of needs assessment in a 'bottom-up' approach, rather than a 'top-down' (a common element with electrification). Thus, two alternatives for parties interested in clean lighting services will be available - PV/SHS and solar lantern; the former, more costly than the latter. But, also available is PVP or hybrid of wind pump/PVP for productivity (irrigation agriculture, cottage enterprises, etc), to individuals and groups wanting to augment their production. These energy services that are geared towards productivity are the bedrock to extricating rural people from poverty. The reasoning is that, the application of such productive energy services can create a virtuous growth cycle among poor rural societies; and this cycle will in turn motivate them to crave for other energy services such as lighting, entertainment, education, etc. In other words, the application of energy services for production (irrigation and other cottage industries) can increase incomes, and the ripple effect of such an increase is the ability to afford other modern energy services.

\section{References}

[1] The EU Initiative, Increasing access to energy for poverty eradication and sustainable development, 2006, pp. 1-11.

[2] S. Bawakyillenuo, Policy and institutional failures: the bane of photovoltaic solar household system (PV/SHS), Energy and Environment Journal, No. 6, 2009, pp. 927-947.

[3] DFID, Energy for the poor. Underpinning the Millennium Development Goals, 2002, pp. $1-32$.

[4] IEA, World Energy Outlook 2002, second edition, 2002.

[5] C. Flavin and M. Aeck, Energy for development. The potential role of renewable energy in meeting the millennium development goals, 2004, pp. 1-45.

[6] A. Niez, 2010, Comparative study on electrification policies in emerging economies, 2010, pp. 1-116.

[7] R. Duke, D. Jacobson, A. Kammen, Photovoltaic module quality in the Kenyan solar home systems market, Energy Policy Journal, Vol. 30, Issue 6, 2002, pp. 477-499.

[8] S. Karekezi, Poverty and energy in Africa - a brief review, Energy Policy Journal, Vol. 30, Issues 11-12, 2002, pp. 915-919.

[9] IEA-PVPS T9-07, 16 case studies on the deployment of PV technologies in developing countries, 2003, pp. 1-115.

[10]V. Radulovic, Are new institutional economies enough? Promoting PV in India's agricultural sector, Energy Policy Journal, Vol. 33, pp. 1883-1899.

[11]Ramakumar, Renewable energy utilisation scenarios: a case for IRES in developing countries, Proceedings of ISES Solar World Congress, 2007, pp. 2917-2921.

[12]S. Bawakyillenuo, Rural electrification in Ghana: issues of photovoltaic utilisation, Unpublished Ph.D. thesis, University of Hull, pp. 1-379.

[13]C. Abavana, Ghana: energy and poverty reduction strategy. EU energy initiative's facilitation workshop and policy dialogue, Ouagadougou, Burkina Faso, 2004.

[14]CIA World Factbook-Ghana, 2007. 